\title{
Maine judge refuses to quarantine nurse who cared for Ebola patients
}

\author{
Michael McCarthy
}

Seattle

A judge in Maine has refused to allow the state to quarantine a nurse who recently returned from Sierra Leone where she had cared for patients with Ebola virus disease.

The state had wanted to keep the nurse, 33 year old Kaci Hickox, quarantined in her home for 21 days, but Hickox said that she did not intend to obey the state's orders, arguing that it was sufficient for her to participate in a monitoring program recommended by the Centers for Disease Control and Prevention (CDC).

Maine's quarantine order was based on politics not science, Hickox said. "All the scientific, medical, and public health community agree with me, and I'm really glad that the judge also agreed," Hickox told the NBC Sunday news program Meet the Press.

Although people can be infected with the Ebola virus and not show symptoms, they are not contagious until they develop symptoms. Guidelines issued by the CDC on 27 October recommended that contacts such as Hickox who have taken care of patients with Ebola virus disease and are, therefore, at "some risk" of infection but who are without symptoms should be checked by a public health worker for fever and symptoms once a day for 21 days after the contact's last potential exposure to the virus, a protocol called direct active monitoring.

Hickox arrived in New Jersey from west Africa on 24 October, shortly after that the state announced that it would quarantine anyone who had been in the three Ebola affected countries, Guinea, Sierra Leone, and Liberia. Several US states have since adopted similar policies.

After she had spent several hours in detention, a measurement with a forehead scanner indicated that Hickox had a temperature of $101^{\circ} \mathrm{F}\left(38.3^{\circ} \mathrm{C}\right)$. Hickox challenged the accuracy of the reading, saying that she was flushed at the time. Nevertheless, she was transported under police escort to an isolation tent outside University Hospital in Newark, New Jersey. Subsequent measurements with oral thermometers found that she had no fever, and blood tests found no sign of the virus. ${ }^{2}$

Hickox objected to her detention, retained well known civil liberties lawyers, and threatened to file suit. After holding her in the isolation tent over the weekend, New Jersey health officials agreed to allow her to travel to her home in Maine, where health officials said they would continue to keep her quarantined. But on arrival in Maine Hickox said that she had no intention to stay in voluntary quarantine and, with reporters in tow, took a bike ride with her boyfriend as police cruisers followed at a distance.

The state went to court to seek legal authority to enforce the quarantine, but after initially granting that authority Charles $\mathrm{C}$ LaVerdiere, chief judge of the Maine District Court, reversed his decision on 31 October and refused to restrict Hickox's movements. "The State had not met its burden at this time to prove by clear and convincing evidence that limiting [Hickox's] movement to the degree requested is 'necessary to protect other individuals from the dangers of infection," LaVerdiere wrote. In his decision LaVerdiere ordered Hickox to continue to participate in the direct active monitoring program but lifted the state's restrictions on her movements. However, LaVerdiere noted that "misconceptions, misinformation, bad science, and bad information" were being spread "from shore to shore in our country with respect to Ebola" and asked Hickox to guide her actions with the understanding that people were fearful.

"Whether that fear is rational or not, it is present and it is real," he said.

Talking to the press outside her home after the judge's decision, Hickox said that she was sensitive to the community's concerns and would not go into town or into crowded places. "I don't want to make anyone uncomfortable," she said.

Access all of The BMJs content on the ongoing Ebola outbreak at thebmj.com/ebola.

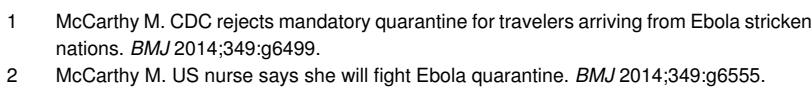

